\title{
Basics of the approach formation to substantiate the temperature field distribution during experimental research on the coal gasification processes
}

\author{
Pavlo Saik ${ }^{1 *}$, Vasyl Lozynskyi ${ }^{1}$, Yurii Chemeriachko ${ }^{2}$, and Edgar Cabana ${ }^{3}$ \\ ${ }^{1}$ Dnipro University of Technology, Department of Underground Mining, 19 Yavornytskoho Ave., \\ 49005 Dnipro, Ukraine \\ ${ }^{2}$ Dnipro University of Technology, Department of Labor Safety and Civil Security, 19 Yavornytskoho \\ Ave., 49005 Dnipro, Ukraine \\ ${ }^{3}$ Universidad Nacional de San Agustin de Arequipa, Institute of Renewable Energy Research and \\ Energy Efficiency, 107 San Agustin Str., Arequipa 04000, Peru
}

\begin{abstract}
This paper studies the problems related to the research on the temperature conditions during the coal seam gasification. In particular, while maintaining the identity of the "model - nature" system. A review of the specific application of thermal imaging equipment and thermoelectric transducers (thermocouples) is given. Approaches to the research into the gasification modes using thermocouples on a laboratory setup are described and the main disadvantages of their application are revealed. The dependences have been obtained of the change in the temperature field depending on the gasification modes (ignition process, reverse operations, gasification mode). Recommendations have been developed on the possibility of using thermal imaging equipment (thermal imagers) when studying the temperature field of the gasification process in laboratory conditions.
\end{abstract}

\section{Introduction}

Today, the innovative development of the basic sectors in Ukraine (metallurgical, chemical and petrochemical, mining, construction, etc.) is mainly based on the phenomena of studying energy-intensive temperature processes. They are based on the parameters of maintaining the recommended temperature conditions, the regulation of which enables efficient control of physical-mechanical and chemical properties of materials [1,2].

As part of the mining industry development, the study of sustainable conditions is the most important for the substantiation and implementation of geotechnologies in mining of mineral deposits [3-8]. For example, in underground fusion, which is widely used for the extraction of native sulphur, bitumen, ozokerite, heavy crude oil, etc., knowledge about the operating temperature range is extremely important $[9,10]$. This makes it possible to assess the efficiency of fusion processes, as well as to substantiate the parameters of technology

\footnotetext{
* Corresponding author: saik.nmu@gmail.com
} 
and the selection of technical equipment. Providing environmental monitoring of post mining area is also important issue $[11-13]$.

Another example of a technology that requires knowledge about the temperature field propagation is well underground coal gasification [14,15]. Knowing the rational parameters of the temperature field propagation in the rock massif, it is possible to characterize the rate of combustion face advance [16], the need to introduce a reverse operation mode $[17,18]$, to determine the parameters of the heat and mass gasification balance [19].

Today, the field of application of thermal imaging devices (infrared radiation) and temperature sensors, the operation principle of which is based on the use of the thermoelectric effect to measure temperature, has become widespread [20].

The use of thermal imaging systems is an effective remote method for obtaining information about the thermal state of the studied objects. Processing and analysis of the obtained thermograms make it possible not only to quickly diagnose the thermal state of the object and its functional capability, but also to characterize the spatial-temporal temperature distribution. A peculiarity of using infrared radiation devices is that the measurement results depend on the value of the emissivity coefficient of the studied object surface. This coefficient depends on temperature, radiation wavelength and type of material. As indicated in the work [21,22], despite certain progress and success in obtaining sufficient information about the emissivity coefficients, the tasks are still unsolved, for which a limited amount of information about this coefficient is used.

Active research is being conducted in this direction both in Ukraine and abroad. In the work [23], it is noted that the main problem when measuring temperature with infrared measuring devices is the low accuracy of determining the thermal condition of the studied object. It is caused by the factors of surrounding medium, the impact of which on the measurement results is difficult to take into account. The measurement accuracy is influenced by the following factors: the absence of normative documents regulating the measurement procedure; introduction of a priori information into the thermal imager system about the parameters of the study, the values of which are subjectively chosen by the researcher; the radiating properties of the studied object surface; background radiation from foreign objects; permeable property of the medium, etc.

Temperature sensors (thermocouples) are another means of measuring and determining the parameters of the temperature field propagation [24]. Their principle of operation is based on the use of the thermoelectric effect (Seebeck effect) to measure temperature [25]. Gas non-volatile setups are the most widespread area of their application. Tungstenrhenium thermocouples are the highest-temperature contact sensors of temperature that are essential in metallurgy for monitoring the temperature of molten metals [26].

At the same time, the use of thermocouples also has a number of disadvantages, namely: it is difficult to achieve the accuracy of more than $1{ }^{\circ} \mathrm{C}$; it is necessary to use resistance thermometers or thermistors; it is necessary to turn off the current passing through the thermocouple, as it cools the hot junction and heats up the cold one (Peltier effect) [27]; thermoelectric inhomogeneity arises as a result of sharp temperature changes, mechanical stresses, corrosion and chemical processes in conductors, which leads to a change in the calibration characteristic and errors up to $5^{\circ} \mathrm{K}$; at great lengths of thermocouple and extension cords for existing electromagnetic fields, an "antenna" effect can occur.

Thus, the purpose of this work is to form an approach to substantiating the parameters of the temperature field distribution using thermal imaging devices and temperature sensors when conducting research on coal gasification in laboratory conditions. 


\section{Methods}

When studying the coal gasification processes, in particular the nature of the temperature field distribution, a mathematical formulation of the non-stationary heat conduction tasks is laid. That is, when the temperature changes over time from one point in space to another, such a field corresponds to the thermal regime of heat conduction, which has not been established, and is called a non-stationary temperature field. Solution of the non-stationary heat conduction tasks is based on finding the dependences of the temperature and the amount of transferred heat in time for any point of the studied area. Mathematically, the non-stationary temperature field can be described by the equation [28]:

$$
t=f(x, y, z, \tau) ; t=f(\tau) ; d t / d \tau \neq 0,
$$

where, in general form, temperature is a function of space $(x, y, z)$ and time $(\tau)$ coordinates.

The link between the temporal and spatial temperature change at an arbitrary point of the body within the studied area of the modelled underground gas generator can be described by the Fourier-Kirchhoff differential equation [29]:

$$
c_{v} \rho \frac{\partial t}{\partial \tau}=\frac{\partial}{\partial x}\left(\lambda \frac{\partial t}{\partial x}\right)+\frac{\partial}{\partial y}\left(\lambda \frac{\partial t}{\partial y}\right)+\frac{\partial}{\partial z}\left(\lambda \frac{\partial t}{\partial z}\right)+q_{v},
$$

where $c_{v}$ is volumetric heat capacity, $\mathrm{J} /\left(\mathrm{m}^{3} \cdot \mathrm{K}\right) ; \rho$ is density of the studied area, $\mathrm{kg} / \mathrm{m}^{3} ; \lambda$ is heat conduction coefficient, $\mathrm{W} /(\mathrm{m} \cdot \mathrm{K}) ; q_{v}$ is specific capacity of internal heat sources, $\mathrm{W} / \mathrm{m}^{3}$.

Since the modelled area of the underground gas generator is an anisotropic medium, the heat conduction of which depends on the direction, therefore, equation (1) takes the form:

$$
c_{v} \rho \frac{\partial t}{\partial \tau}=\sum_{i=1}^{n-1} \frac{\partial}{\partial x_{i}}\left(\lambda \frac{\partial t}{\partial x_{i}}\right)+q_{v} .
$$

Application of the above mathematical tool allows to quantify the nature of the temperature field propagation around the modelled area of the underground gas generator. At the same time, for determining the qualitative characteristics, it is necessary to take into account the parameters of the change in the length of the combustion face both by the burning front area and by the gasification column length, as well as the parameters of the balance between the oxidizing and reducing zones of chemical reactions. The ratio of the temperature field indicators arising in the model and the natural object can be described by the expression:

$$
\frac{T_{\max . \text { nat. }}^{\text {ox.z. }}}{T_{\max . \bmod .}^{\text {ox.z. }}}=\frac{T_{\text {max. } n a t .}^{\text {red.z. }}}{T_{\max . \text { mod. }}^{\text {red.z. }}}=x_{T}=\text { const },
$$

where $T_{\text {max.nat. }}^{\text {ox.z. }}, T_{\text {max.mod. }}^{\text {ox.z. }}$ - the maximum oxidizing zone temperature of the underground gas generator in the natural object and the model, respectively, ${ }^{\circ} \mathrm{C} ; T_{\max . n a t .}^{\text {red.z. }}, T_{\max . \text { mod. }}^{\text {red.z. }}-$ the maximum reducing zone temperature of the underground gas generator in the natural object and the model, respectively, ${ }^{\circ} \mathrm{C}$.

A peculiarity of research into non-stationary phenomena, in our case, the velocity of the combustion face movement, is the necessity to determine temporal similarity. That is, at a certain time in the natural object $t_{\text {nat }}$. and the model $t_{\text {mod. }}$, there is a change in the temperature field, which in similar points of the natural object and the model has the values 
$T_{\text {nat }}$ and $T_{\text {mod. }}$. After a certain period of time $t_{\text {nat. }}^{1}$ and $t_{\text {mod. }}^{1}$ the temperature will change by $T_{\text {nat. }}^{1}$ and $T_{\text {mod. }}^{1}$, respectively, etc.

Given that $\frac{T_{\text {nat. }}}{T_{\text {mod. }}}=\frac{T_{\text {nat. }}^{1}}{T_{\text {mod. }}^{1}}=\frac{T_{\text {nat. }}^{2}}{T_{\text {mod. }}^{2}}=\frac{T_{\text {nat. }}^{i}}{T_{\text {mod. }}^{i}}=x_{T}=$ const, and $\frac{t_{\text {nat. }}}{t_{\text {mod. }}}=\frac{t_{\text {nat. }}^{1}}{t_{\text {mod. }}^{1}}=\frac{t_{\text {nat. }}^{2}}{t_{\text {mod. }}^{2}}=$ $=\frac{t_{\text {nat. }}^{i}}{t_{\text {mod. }}^{i}}=x_{t}=$ const the phenomenon of homochronicity is provided.

It is possible to determine the parameters of the temperature field propagation during underground coal gasification by conducting analytical, laboratory and field studies. Application of analytical studies, since this area is non-stationary, requires introducing the appropriate correction coefficients into the mathematical model, which characterize the change in the position of the combustion face depending on the parameters of the formation of chemical reactions zones in it. Conducting laboratory and field studies provides testing of these coefficients. It should be noted that the main disadvantage of conducting field studies is their cost. Therefore, preference is given to laboratory studies. When studying the parameters of the temperature field propagation in laboratory conditions using thermal imaging devices and temperature sensors, a number of necessary clarifications arise.

For example, in the work [30], using the thermal imaging devices, the parameters have been determined of the formation of an artificially created shell of fused rocks around the combustion face during research on a bench setup, modelling the conditions of the Barbara mine in Poland. The given thermogram shows the geometry of the temperature field propagation. At the same time, its analysis does not make it possible to quantify the temperature field indicators.

When conducting research, the obtained results reliability should be ensured by similarity criteria, under which the following conditions are satisfied: natural materials by their physical properties correspond to natural conditions of the studied mining areas [31 33]; the geometrical parameters of the gasification section are reproduced in the model ensuring the principles of static similarity; the lithological structure of the rock-coal stratum takes into account its change in area; providing a hierarchical subordination to factors that form a stress-strain state of the rock massif; the technological effectiveness of the coal gasification process is ensured by the balanced course of chemical reactions and physical velocities. Photo fixation of the laboratory setup is shown in Fig. 1.

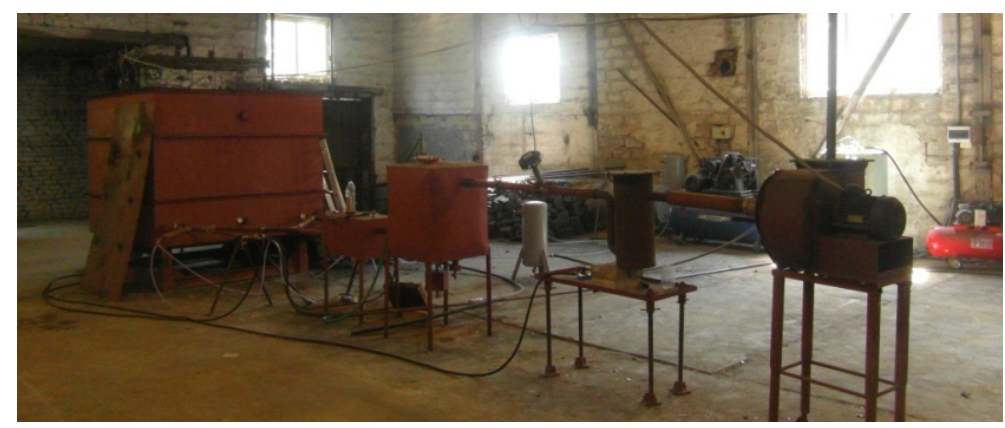

Fig. 1. Photo fixation of the laboratory setup: 1 -sectional laboratory stand, 2 -cooler tank for sampling, 3 - smoke sucker, 4 -a tank for supplying the blowing reagents; 5 -reverse T-junction; 6 - controlled blowing pipelines; 7 - blowing pipelines; 8 -pipeline for simulation of the "well-gas generator" technology; 9 - ignition channel. 
The components of a laboratory setup for studying gasification processes are: a laboratory stand made in the form of a sectional metal box intended for the reproduction of a coal massif; systems to supply blowing mixtures and reagents; a gas exhaust system intended to remove the generator gas and setting the energy gases concentration by sampling method and control-measuring equipment.

The ignition of the laboratory gas generator is controlled using a pyrometer with a K-type thermocouple $30: 1\left(-50 \ldots+1350{ }^{\circ} \mathrm{C}\right)$ FLUS IR-823. The coal seam is ignited through a side opening with a diameter of $100 \mathrm{~mm}$ using hot pieces of coal and the supply of an oxygenenriched blowing $\left(\mathrm{O}_{2}-\right.$ up to $\left.40 \%\right)$. This process has led to the source formation of a coal seam ignition under the temperature condition of $435-515{ }^{\circ} \mathrm{C}$. The front of the seam heating coincides with the movement of blowing in the direction of the direct burning through of the reaction channel of the gas generator. The process of the reaction channel zones formation takes about 1.2 hours.

Temperature sensors are set in the roof of the modelled coal seam in four rows. The distance between them is $0.25 \mathrm{~m}$ by the combustion face length and $0.3 \mathrm{~m}$ by the gasification column length. It makes possible to assess the rate of the burning front advance. The first row of thermocouples is located at a distance of $0.1 \mathrm{~m}$ from the combustion face.

\section{Results and discussion}

The temperature field maximum is observed from the side of the blowing well. This is conditioned by the chemical reactions intensity, which directly depend on the intensity of blowing to the coal seam reaction surface. In the oxidizing zone of the gas generator, which is located from the side of the blowing well, there is an advance of the combustion face line. The temperature field distribution for 1.2 hours of the reaction channel zones formation is shown in Fig. 3.

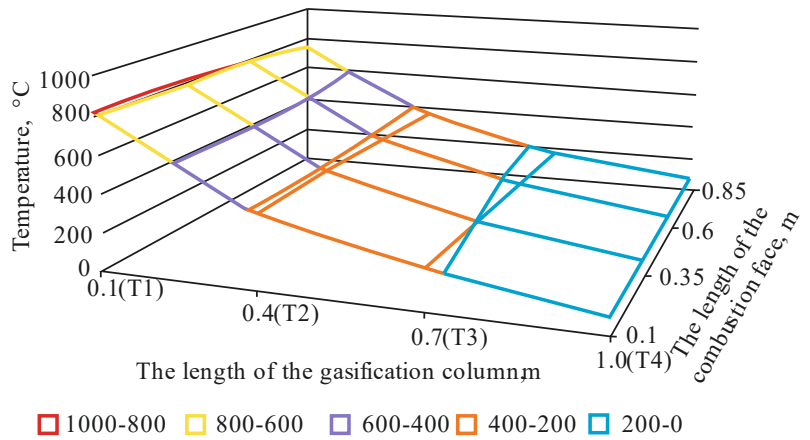

Fig. 1. The temperature field propagation in the roof of the modelled seam for 1.2 hours of the reaction channel zones formation.

Accordingly, its length and the length of its movement towards the blowing well increase. Thus, along the length of the combustion face, the temperature changes according to a polynomial dependence of the second stage, where the temperature maximum is observed from the side of the blowing well $\left(R^{2}=0.97-0.99\right)$ :

$$
\begin{gathered}
T_{1}=-264 l^{2}+6 l+556.54 ; \\
T_{2}=-384 l^{2}+79.2 l+506.02 ; \\
T_{3}=-472 l^{2}+165.2 l+446.9 ; \\
T_{4}=-328 l^{2}-19.6 l+429.44,
\end{gathered}
$$


where $T_{1}-T_{4}$ are the nature of the temperature change along the rows of thermocouples along the length of the combustion face, ${ }^{\circ} \mathrm{C} ; l$ is position of a thermocouples row along the length of the combustion face, $\mathrm{m}$.

This character of the temperature field distribution does not provide the stability of the modelled gas generator changeover to the gasification mode. To solve this problem, the authors propose to transfer the modelled gas generator to the reverse mode. It is known that coal combustion occurs in the oxidation zone of the gas generator. The process of carbon and oxygen combustion from the air, directed into the modelled gas generator, occurs by primary reactions with the carbon dioxide formation. Gaseous products of primary reactions react with fuel carbon, oxygen, water vapour and with each other and form the socalled secondary reactions [34].

The most important secondary gasification reaction is the heterogeneous reducing reaction $\mathrm{CO}_{2}$ into $\mathrm{CO}\left(\mathrm{C}+\mathrm{CO}_{2}=2 \mathrm{CO} \pm q\right.$, where $q$ is thermal energy generated during the reactions). This reaction is decisive and determines the amount of gas obtained and the uniformity of the combustion face movement. In this case, the temperature condition in the reduction zone should be above $800^{\circ} \mathrm{C}$. To achieve the indicators of the specified temperature for 1.2 hours of the experiment, the modelled gas generator is transferred to reverse mode. The indicators of thermocouples are controlled every 15 minutes. After 0.75 hours of the reverse mode, the following temperature distribution pattern is obtained, shown in Fig. 3.

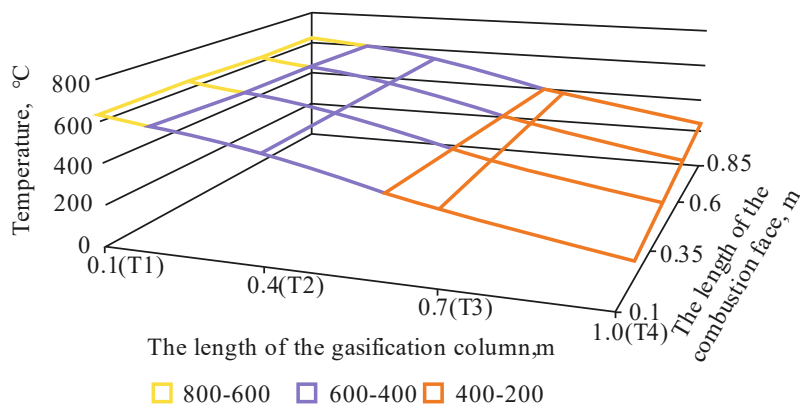

Fig. 3. Propagation of the temperature field in the roof of the modelled seam after 0.75 hours of reverse operation: position of thermocouples along the length of the gasification column, m; position of thermocouples along the length of the combustion face, $\mathrm{m}$; temperature, ${ }^{\circ} \mathrm{C}$.

Data analysis (Fig. 3) evidences that the temperature field began to expand uniformly into the depth of the massif, and the combustion face began to level up along its length. And the temperature condition on the first row of T1 thermocouples has set in the range of $768-932^{\circ} \mathrm{C}$. This evidences that the combustion process began a changeover to the gasification process. This statement is also confirmed by an increase in the concentration of methane in the initial mixture from 2.4 to $11.8 \%$.

It is extremely important to know about the temperature condition of the modelled gas generator. It gives an ability to assess the indicators of its effectiveness and characterize the need for reverse work. At the same time, the study of the temperature in a gas generator using stationary devices (thermocouples) is a time-consuming process. It is necessary to lay down each thermocouple separately, isolate additionally the places where the thermocouples are laid in the upper cover of the laboratory stand, because they can be damaged carelessly, and additional equipment should be used to connect them, such as an intelligent measuring transducer with the ability to archive measurement data and a communication interface with a PC, the PC itself, and a compensation cable. Having assessed the complexity of the research into the thermal field with thermocouples, the 
authors of the work have developed recommendations for the use of thermal imaging devices (thermal imagers) when studying the coal gasification under laboratory conditions.

Today, there is a large number of manufacturers of thermal imagers and models that can be adapted to the study of coal gasification processes. The result of the thermal imager operation, as previously noted, is a thermogram - an image in the infrared band.

The main research object is a sectional laboratory stand (1) shown in Fig. 1. To substantiate the parameters of the thermal field propagation and the possibility of comparing the data obtained from the thermocouples, it is necessary to obtain a surface thermogram of the stand, namely, from the side of the cover. The general scheme of the measurement process is shown in Fig. 4.

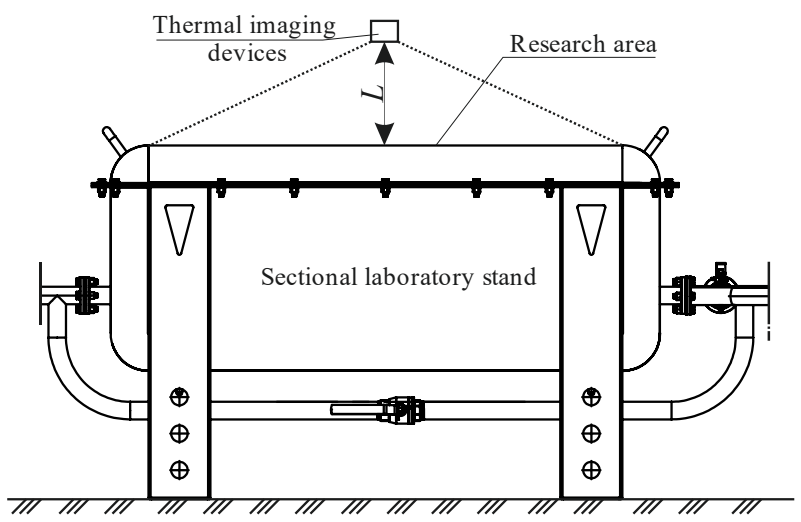

Fig. 4. Scheme of the temperature measuring process.

To determine the parameters of the thermal field propagation directly in the roof of the combustion face during the gasification process of the modelled coal seam, it is necessary to compare the data of thermography and thermocouples. Accordingly, with a changeover to the reverse mode for 1.2 hours of the experiment, and after 0.75 hours. The position of the measuring points for temperatures from the thermograms should be accepted at the places where the thermocouples are set. This makes it possible to determine the temperature coefficient:

$$
k_{t_{i}}=\frac{t_{T_{i}^{m}}}{t_{T_{i}^{t h}}},
$$

where $t_{T_{i}^{m}}$ is temperature indicators in the combustion face roof determined by means of thermocouples, ${ }^{\circ} \mathrm{C}, t_{T_{i}^{t h}}$ is temperature indicators determined from thermograms in places of set thermocouples, ${ }^{\circ} \mathrm{C}$.

Determination of this coefficient provides the ability to quickly find the temperature indicators in the roof of the combustion face, without additional installation of thermocouples.

\section{Conclusions}

An important component of research into the coal gasification processes under laboratory conditions is the determination of the temperature field propagation parameters. In the process of the coal seam ignition, the combustion face acquires a curvilinear shape, with an advance in the area of the blowing well mouth. This is evidenced by the change in the 
temperature field nature according to a polynomial dependence. Consequently, the mathematical tool for solving the non-stationary heat conduction tasks does not make it possible to assess a change in the temperature and the amount of transferred heat in time for the curvilinear shape of the combustion face. It is a time-consuming process to study the temperature field with stationary devices. Another option is the studied object thermography. In this case, it is necessary to determine the temperature coefficient $\left(k_{t}\right)$, which characterizes a change in the temperature field according to the studied rows of thermocouples. This provides data on the temperature field propagation around the modelled underground gas generator.

By means of further research, it is planned in laboratory conditions to obtain thermographic images of the temperature field distribution around the modelled combustion face, to propose a mathematical tool for determining the parameters of this field propagation, depending on the modes of the blowing mixture supply and the mininggeological conditions of coal seams occurrence.

This work is conducted within the framework of scientific works and scientific-technical (experimental) developments of young scientists "Synthesis, optimization and parameterization of innovative technologies for mining the resources of gas-coal deposits" under the support of the Ministry of Education and Science of Ukraine (State registration No. 0119U000248).

\section{References}

1. Piwniak, G.G., Bondarenko, V.I., Salli, V.I., Pavlenko, I.I., \& Dychkovskiy, R.O. (2007). Limits to economic viability of extraction of thin coal seams in Ukraine. Technical, Technological and Economic Aspects of Thin-Seams Coal Mining International Mining Forum 2007, 129-132. https://doi.org/10.1201/noe0415436700.ch16

2. Dreus, A.Yu., Sudakov, A.K., Kozhevnikov, A.A., Vakhalin, Yu.N. (2016). Study on thermal strength reduction of rock formation in the diamond core drilling process using pulse flushing mode. Naukovyi Visnyk Natsionalnoho Hirnychoho Universytetu, (3), 5-10.

3. Bondarenko, V., Symanovych, G., \& Koval, O. (2012). The mechanism of over-coal thin-layered massif deformation of weak rocks in a longwall. Geomechanical Processes During Underground Mining, 41-44. https://doi.org/10.1201/b13157-8

4. Abdiev A., Mambetova, R., Abdiev, A., \& Abdiev S. (2020). Development of methods for assessing the mine workings stability. E3S Web of Conference. Preprint.

5. Małkowski, P., Niedbalski, Z., \& Hydzik-Wiśniewska, J. (2013). The Change of Structural and Thermal Properties of Rocks Exposed to High Temperatures in the Vicinity of Designed GeoReactor. Archives of Mining Sciences, 58(2), 465-480.

6. Małkowski, P., Niedbalski, Z., \& Hydzik-Wiśniewska, J. (2013). The Change of Structural and Thermal Properties of Rocks Exposed to High Temperatures in the Vicinity of Designed GeoReactor. Archives of Mining Sciences, 58(2), 465-480. https://doi.org/10.2478/amsc-2013-0031

7. Sotskov, V., \& Saleev, I. (2013). Investigation of the rock massif stress strain state in conditions of the drainage drift overworking. Annual Scientific-Technical Collection - Mining of Mineral Deposits, 197-201. https://doi.org/10.1201/b16354-35

8. Babets, D.V., Sdvyzhkova, O.O., Larionov, M.H., Tereshchuk, R.M. (2017). Otsinka stiikosti masyvu hirskykh porid, shcho bazuietsia na ymovirnisnomu pidkhodi ta reitynhovykh klasyfikatsiiakh. Naukovyi Visnyk Natsionalnoho Hirnychoho Universytetu, (2), 58-64.

9. Bondarenko, V.I., Kharin, Ye.N., Antoshchenko, N.I., \& Gasyuk, R.L. (2013). Basic scientific positions of forecast of the dynamics of methane release when mining the gas bearing coal seams. Naukovyi Visnyk Natsionalnoho Hirnychoho Universytetu, (5), 24-30.

10. Beshta, O.S. (2012). Electric drives adjustment for improvement of energy efficiency of technological processes. Naukovyi Visnyk Natsionalnoho Hirnychoho Universytetu, (4), 98-107. 
11. Gorova, A., Pavlychenko, A., \& Borysovs'Ka, O. (2013). The study of ecological state of waste disposal areas of energy and mining companies. Annual Scientific-Technical Collection - Mining of Mineral Deposits, 169-172. https://doi.org/10.1201/b16354-29

12. Buzylo, V., Pavlychenko, A., Savelieva, T., \& Borysovska, O. (2018). Ecological aspects of managing the stressed-deformed state of the mountain massif during the development of multiple coal layers. E3S Web of Conferences, (60), 00013. https://doi.org/10.1051/e3sconf/20186000013

13. Khomenko, O., Kononenko, M., \& Myronova, I. (2013). Blasting works technology to decrease an emission of harmful matters into the mine atmosphere. Annual Scientific-Technical CollectionMining of Mineral Deposit, 231-235. https://doi.org/10.1201/b16354-43

14. Saik, P., Petlevanyi, M., Lozynskyi, V., Sai, K., \& Merzlikin, A. (2018). Innovative approach to the integrated use of energy resources of underground coal gasification. Solid State Phenomena, (277), 221-231. https://doi.org/10.4028/www.scientific.net/SSP.277.221

15. Dychkovskyi, R., Vladyko, O., Maltsev, D., Cabana, E.C. (2018). Some aspects of the compatibility of mineral mining technologies. Rudarsko-Geološko-Naftni Zbornik, 33(4), 73-82. https://doi.org/10.17794/rgn.2018.4.7

16. Lozynskyi, V.H., Dychkovskyi, R.O., Falshtynskyi, V.S., \& Saik, P.B. (2015). Eksperymentalni doslidzhennia vplyvu perekhodu dyziunktyvnoho heolohichnoho porushennia na temperaturnyi rezhym pidzemnoho hazoheneratora. Naukovyi Visnyk Natsionalnoho Hirnychoho Universytetu, (4), 22-28.

17. Liu, H., Chen, F., Wang, Y., Liu, G., Yao, H., \& Liu, S. (2018). Experimental Study of Reverse Underground Coal Gasification. Energies, 11(11), 2949. https://doi.org/10.3390/en11112949

18. Blinderman, M. S., Saulov, D. N., \& Klimenko, A. Y. (2008). Forward and reverse combustion linking in underground coal gasification. Energy, 33(3), 446-454. https://doi.org/10.1016/j.energy.2007.10.004

19. Lozynskyi, V., Dychkovskyi, R., Saik, P., Falshtynskyi, V. (2018). Coal Seam Gasification in Faulting Zones (Heat and Mass Balance Study). Solid State Phenomena, (277), 66-79. https://doi.org/10.4028/www.scientific.net/SSP.277.66

20. Teplovizory. (2020). Klassifikatsiya teplovizorov i poluchenie imi izobrazheniya. [online] Available at: https://teplovizo.ru/klassifikaciya-teplovizorov.htm

21. Stavorovskiy, K.M. (2014). Avtomaticheskaya diagnostika i analiz termogramm v meditsinskoy praktike. Electronics and communications, 19(1), 47-5.

22. Levynskyi, O.S., Holofieieva, M.O., Shvorin, V.O., \& Ursol, S.M. (2017). Eksperymentalne doslidzhennia temperatury ob'iekta pryladamy infrachervonoi tekhniky. Zbirnyk naukovykh prats Odeskoi derzhavnoi akademii tekhnichnoho rehuliuvannia ta yakosti, (1), 46-50.

23. Dzikovs'ka, Yu.M. (2017). Normayvno-tekhnichne zabezpechennia vimiriuvan rozpodilu temperatury teplovoho polia obiektiv promyslovosti ta medytsyny. Ph.D. Lviv Politechnic.

24. Lutsyk, Ya.T., Huk, O.P., Lakh, O.I., \& Stadnyk, B.I. (2006). Vymiriuvannia temperatury: teoriia ta praktyka. Lviv: Vydavnytsvo "BeskydBit", $560 \mathrm{~s}$.

25. Kozma, A.A., Peresh Ye.Yu., Barchii I.Ye., \& Cabov M.Yu (2011). Do 190-richchia vidkryttia efektu Zeiebeka. Scientific Bulletin of the Uzhgorod University, 1(25), 26-31.

26. KVOTA. (2014). Termopara ta pryntsypy yii zastosuvannia. [online] Available at: https://www.kvota.com.ua/statti/termopara/

27. Freik, D.M., Nykyrui, L.I., Halushchak, M.O., \& Mateik, H.D. (2012). Dosiahnennia i problemy termoelektryky. II. Fizyka i khimiia tverdoho tila, 13(3), 574-585.

28. Hilchuk, A.V., \& Khalatov, A.A. (2017). Teoriia teploprovidnosti. Chastyna 1. Kyiv, 86 s.

29. Kulinchenko, V.R., Shevchenko, O.Yu., \& Piddubnyi, V.A. (2014). Teploviddacha z elementamy masoobminu (teoriia i praktyka protsesu). Kyiv: Feniks, $918 \mathrm{~s}$.

30. Dychkovskyi, R.O. (2015). Forming the bilayer artificially created shell of georeactor in underground coal well gasification. Naukovyi Visnyk Natsionalnoho Hirnychoho Universytetu, (5), 37-42. 
31. Sdvizhkova, Ye.A., Babets, D.V., \& Smirnov, A.V. (2014). Analiz zakonomernostey formirovaniya nagruzki na krep' pri proektirovanii montazhnikh kamer strugovykh lav $\mathrm{V}$ usloviyakh shakht Zapadnogo Donbasa. Naukovyi Visnyk NHU, (5). 26-32.

32. Sobko B., Lozhnikov O., Levytskyi V., \& Skyba G. (2019). Conceptual development of the transition from drill and blast excavation to non-blasting methods for the preparation of mined rock in surface mining. Rudarsko Geolosko Naftni Zbornik, 34(3), 21-28. https://doi.org/10.17794/rgn.2019.3.3

33. Gorova, A., Pavlychenko, A., Borysovs'ka, O., \& Krups'ka, L. (2013). The development of methodology for assessment of environmental risk degree in mining regions. Annual ScientificTechnical Colletion - Mining of Mineral Deposit, 207-209. https://doi.org/10.1201/b16354-38

34. Sobolev, V.V. (1999). O genezise kamennogo uglya. Gornyy informatsionno-analiticheskiy byulleten', (3), 107-110. 